\title{
IN VITRO ANTIOXIDANT AND IN VIVO ANTIDIABETIC ACTIVITY OF TWO POTENTIAL PROBIOTIC ENTEROCOCCUS SPP. ON ALLOXAN-INDUCED DIABETIC RATS
}

\author{
KAMNI RAJPUT*, RAMESH CHANDRA DUBEY \\ Department of Botany and Microbiology, Gurukula Kangri (Deemed To Be University), Haridwar, Uttarakhand, India. \\ Email: kamnirajput20@gmail.com
}

Received: 20 November 2020, Revised and Accepted: 09 December 2020

\section{ABSTRACT}

Objective: In vitro antioxidant activity, in vivo antidiabetic property and intestinal attachment by two potential probiotic bacterial strains, namely, Enterococcus faecium and Enterococcus hirae were studied using albino rats.

Methods: Antioxidant the activity was assessed using 2,2-Diphenyl-1-picrylhydrazyl radicals scavenging assay. Alloxan was administered intraperitoneally to induce diabetic conditions in experimental rats. Animals were treated with oral administration of Enterococcus spp., such as E. faecium, and E. hirae isolated from goat and sheep milk. The control animal group received normal saline for the same days. Glibenclamide drug was used as a positive control against probiotic bacterial cells.

Results: However, administration of probiotic bacterial strains E. faecium and E. hirae, in albino rats significantly (p<0.05) at varying doses lowered blood glucose levels in diabetic rats as compared to the diabetic control group. Both the species of Enterococcus increased the bodyweight of experimental rats. However, E. faecium was the best antidiabetic strain having the antioxidant activities also in comparison to $E$. hirae. The attachment of probiotic bacterial cells E. faecium on the rat's intestine wall against pathogens was examined. Furthermore, E. faecium showed its aggregation with pathogens by attachment of the intestines of albino rats. This showed that both the bacterial strains exhibited in vivo antidiabetic effect.

Conclusion: The results of this study showed that probiotic bacteria possess antioxidant, antidiabetic activities, and attachment of intestine.

Keywords: Probiotics bacteria, Lactic acid bacteria, Enterococcus spp., Antidiabetic effect, Antioxidant activity, Intestinal attachment

(C) 2021 The Authors. Published by Innovare Academic Sciences Pvt Ltd. This is an open access article under the CC BY license (http://creativecommons.org/ licenses/by/4.0/) DOI: http://dx.doi.org/10.22159/ajpcr.2021v14i3.40321. Journal homepage: https://innovareacademics.in/journals/index.php/ajpcr

\section{INTRODUCTION}

Diabetes is one of the common metabolic disorders throughout the world. It is a major health problem affecting millions of people of all gender and age groups worldwide. Diabetes occurs when the body is unable to produce enough insulin or has complications of its proper use [1]. Therefore, it is a multifactor disorder. Defects in reactive oxygen species (ROS) scavenging enzymes, deficiencies or disruptions in insulin secretion, and high oxidative stress damaging pancreatic beta cells will result in chronic hyperglycemia and troublesome disruptions in carbohydrate, fat, and protein metabolisms [2]. The beta-pancreas cells are responsible for insulin production in the human body. Insulin can attach to the cell surface by specific ligands and glucose absorption, increase by cell and blood glucose decrease. Therefore, beta pancreas dysfunctions reducing the insulin level in the blood can cause hyperglycemia disease and blood accumulation [3]. Various studies have demonstrated that hyperglycemiainduced generation of free radicals mediates mainly oxidative stress and contributes to the development and evolution of diabetes [4]. Pancreatic $\beta$-cells are mainly susceptible to the harmful effects of ROS because of its low expression of the genes of antioxidants as compared to other tissues. Thus, the damage of $\beta$-cells is caused by an increase of ROS through the apoptosis-induction and insulin-biosynthesis suppression [5].

The probiotics are "live Microorganisms conferred a health benefit on the host when they are administrated in adequate amounts" [6]. Thus, the preventive effects of probiotic lactic acid bacteria (LAB) on diabetes have recently been demonstrated in several experimental studies. Various antidiabetic agents are available in the market, but their uses have become limited due to severe adversary effects in humans, such as diarrhea, flatulence, and bloating. Hence, there is much interest in using probiotics as health supplements [7]. One of the most important criteria for the selection of these types of strains is the ability of probiotic bacteria to adhere to intestinal surfaces. Attachment of probiotic bacteria to mucosa also influences the host's normal microbiota and gastrointestinal immune system [8]. The most important factors are the attached of probiotics to intestinal epithelial cells and colonization of the intestinal tract because of their importance for maintaining the balance in the normal gut microbiota of the host and affect the ability of the bacterial species to function as a probiotic [9]. Enterococcus faecium and Enterococcus hirae were previously isolated from goat and sheep milk and evaluated for its probiotic properties, including acid and bile tolerance and production of antimicrobial compounds [10]. The present study was undertaken to investigate the in vitro antioxidant activity, in vivo anti-hyperglycemic effect of Enterococcus spp. on alloxaninduced diabetic albino rats and its attachment to the intestinal surface.

\section{METHODS}

Antioxidant activity by 2,2-Diphenyl-1-picrylhydrazyl (DPPH) radical scavenging assay

Antioxidant activity was performed by DPPH radical scavenging assay. Overnight grown bacterial cultures were centrifuged at $5000 \mathrm{rpm}$ for 15 min. Cell-free the supernatant was added with a freshly prepared solution of DPPH at $5 \mathrm{mg} / 100 \mathrm{ml}$ ethanol. Control was prepared using ethanol added to DPPH solution, mixed with dark, and incubated for $30 \mathrm{~min}$. Absorbance was recorded at $517 \mathrm{~nm}$ using a spectrophotometer (Shimadzu, Japan). The percentage of radical scavenging activity was calculated according to the following equation [11].

$$
\text { DPPH activity }=\left(\mathrm{A}_{\text {control }}-\mathrm{A}_{\text {sample }}\right) / \mathrm{A}_{\text {control }} \times 100 .
$$

Preparation of bacterial suspension

The bacterial strains E. faecium and E. hirae used in this study were previously isolated from goat and sheep milk. These bacterial strains were separately cultured on MRS broth and grown at $37^{\circ} \mathrm{C}$ for $24 \mathrm{~h}$. Then, cultures were harvested by centrifugation at $6000 \mathrm{rpm}$ for $20 \mathrm{~min}$. The 
supernatant was decanted as the pellets of bacterial cells were washed twice with sterile phosphate buffer saline (PBS) and re-suspended in PBS to get the final concentration of $10^{8}$ and $10^{9} \mathrm{cfu} / \mathrm{ml}$, respectively, according to McFarland standards.

\section{Test animals}

Healthy albino rats (6-8 weeks old) were obtained from Lala Lajpat Rai University, Hisar (Haryana, India) and kept in the Animal House of the Department of Pharmaceutical Sciences, Gurukula Kangri (Deemed to be University), Haridwar (Animal House Reg. No.: 1324/a/10/CPCSEA). The Institutional Animal Ethical Committee approved the experimental protocol for use of laboratory animals. The rats were maintained in an air-conditioned room at $25^{\circ} \mathrm{C}$ in plastic cages with wood shaving as bedding and fed on commercial balanced sterilized diet pellets and water under standardized conditions.

\section{Dose feeding procedure}

The control groups received pure PBS saline. Each probiotic bacterial suspension of $10^{8} \mathrm{cfu} / \mathrm{ml}$ and $10^{9} \mathrm{cfu} / \mathrm{ml}$, respectively, was administered orally once daily using PBS.

\section{Induction of diabetes in albino rats}

Diabetes was induced intraperitoneally in albino rats by injecting the freshly prepared alloxan dissolved in a normal saline solution of $\mathrm{NaCl} 0.9 \% \mathrm{pH} 4$ at a dose of $40 \mathrm{mg} / \mathrm{kg}$ body weight [12]. After $1 \mathrm{~h}$ of alloxan administration, animals were given feed ad libitum. Blood samples were collected for analysis using glucose test strips after $24 \mathrm{~h}$ of alloxan injection, from the vein at the tip of the tail. Blood glucose levels (BGL) were determined using a glucometer. Blood sugar level (250-350 mg/dl) was considered as a diabetic level.

\section{Acute toxicity test}

The rats were kept on fasting and provided with only water, thereafter E. faecium and E. hirae were administered orally by gastric tube in different gradual doses $\left(10^{7}, 10^{8}, 10^{9}\right.$, and $\left.10^{10} \mathrm{cfu} / \mathrm{ml}\right)$. Expression of any toxic symptoms and rat mortality was observed up to $72 \mathrm{~h}$ [13]

\section{Experimental design}

The animals were divided into seven groups and each group consisted of six animals. All animals were allowed to access feed and water. Group I was untreated rats as normal control. Group II was treated with alloxan monohydrate (at $40 \mathrm{mg} / \mathrm{kg}$ body weight) as diabetic control. Group III was treated with glibenclamide (at $50 \mathrm{mg} / \mathrm{kg}$ body weight) as a positive control. Groups IV and V received E. faecium (at doses of $10^{8} \mathrm{cfu} / \mathrm{ml}$ and $10^{9} \mathrm{cfu} / \mathrm{ml}$ ); and Groups VI and VII were treated with E. hirae (at doses of $10^{8} \mathrm{cfu} / \mathrm{ml}$ and $10^{9} \mathrm{cfu} / \mathrm{ml}$ ) as treatment groups. The blood glucose concentrations of the animals were measured at the beginning of the study and the same were repeated on the $3^{\text {rd }}, 7^{\text {th }}, 14^{\text {th }}$, and $21^{\text {st }}$ days of treatment. All the animals were regularly observed for their general behavior. Changes in body weight were also measured.

\section{Blood sampling and determination of BGL}

Day 3 of induction was designated as day 1 for the administration of the test sample to diabetic rats. Fasting BGL were measured on days $3^{\text {rd }}, 7^{\text {th }}, 14^{\text {th }}$, and $21^{\text {st }}$ of the administration period of test samples. Blood sampling was done by sterilizing the tail with $10 \%$ alcohol and then nipping the tail at the start of the experiment. After blood sampling, the tips of the tail were sterilized by swabbing with $70 \%$ ethanol. The BGL were determined using a glucometer.

\section{Effect of probiotics bacteria on body weight}

The effect of administration of probiotic strains to diabetic mice was determined by measuring the fasting BGL and changes in body weight. The body weight of each experimental set was measured with an electronic balance on $3^{\text {rd }}, 7^{\text {th }}, 14^{\text {th }}$, and $21^{\text {st }}$ days.

In vivo study of intestine attachment of albino rats

After approval granted from the Institutional Animal Ethical Committee (Animal House Reg. No. 1324/a/10/CPCSEA, Government of India), an experiment on albino rats was conducted in the Department of Pharmaceutical Sciences. The rats were divided into four groups and each group contains six animals. All albino rats (4-5 weeks old) were kept in light and dark cycle under standard conditions at a suitable temperature and fed with the standard pellet diet with water ad libitum. Consequent doses of E. faecium were prepared in saline having $10^{9} \mathrm{cfu} / \mathrm{ml}$. These standard doses were given orally to rats after initiating the infection by different pathogens such as Escherichia coli and Salmonella typhimurium.

\section{Excised rats intestine observed by scanning electron microscopy} After 7 days, after administrating the doses, albino rats were sacrificed by cervical dislocation. The small intestine of rats was removed gently. The segmented intestine was opened and washed with PBS. Washed intestine segments were fixed in 4\% glutaraldehyde for 60-70 min and dehydrated using different concentrations of alcohol. Finally, the fixed and dehydrated samples were mounted on aluminum stubs further coated with gold-palladium. Attachment of E. faecium on the intestinal surface was observed by scanning electron microscope at $30 \mathrm{Kv}$ in a LEO 485 VPSEM (ZEISS, USA). Photomicrographs were taken by the same microscope.

\section{Statistical analysis}

The data were analyzed statistically using Microsoft Excel 2010 and represented as a mean of triplicate \pm standard deviation. Oneway analysis of variance (ANOVA) was employed followed by t-test: Two sample assuming equal variances. The values were considered significant level of $\mathrm{p}<0.05$.

\section{RESULTS}

\section{Antioxidant activity}

The antioxidant activity of LAB strains plays an important role in the protection from free radicals. The antioxidant activity of $E$. faecium and E. hirae was measured by DPPH radical scavenging. The DPPH radical scavenging activity of E. faecium was $53.86 \%$ and $65.47 \%$ at $10^{8} \mathrm{cfu} / \mathrm{ml}$ and $10^{9} \mathrm{cfu} / \mathrm{ml}$, which was higher than those of $E$. hirae showing $51.78 \%$ and $59.80 \%$ at $10^{8} \mathrm{cfu} / \mathrm{ml}$ and $10^{9} \mathrm{cfu} / \mathrm{ml}$, respectively. E. faecium posed better antioxidant effects on the basis of radical scavenging activity (Fig. 1).

\section{Antidiabetic activity of $E$. faecium and $E$. hirae}

Glibenclamide administered to experimental animals resulted in a significant $(\mathrm{p}<0.05)$ rise in BGL. Before and after treatment with the test drug in glibenclamide-induced diabetic animals, changes in body weights and fasting BGL were determined. Fasting BGL in untreated diabetic rats were significantly higher $(305.83 \mathrm{mg} / \mathrm{dl})$ and the body weights were lower $(89.50 \mathrm{~g})$ than that of the normal rats. Diabetic animals treated with probiotic bacterial strains showed significant

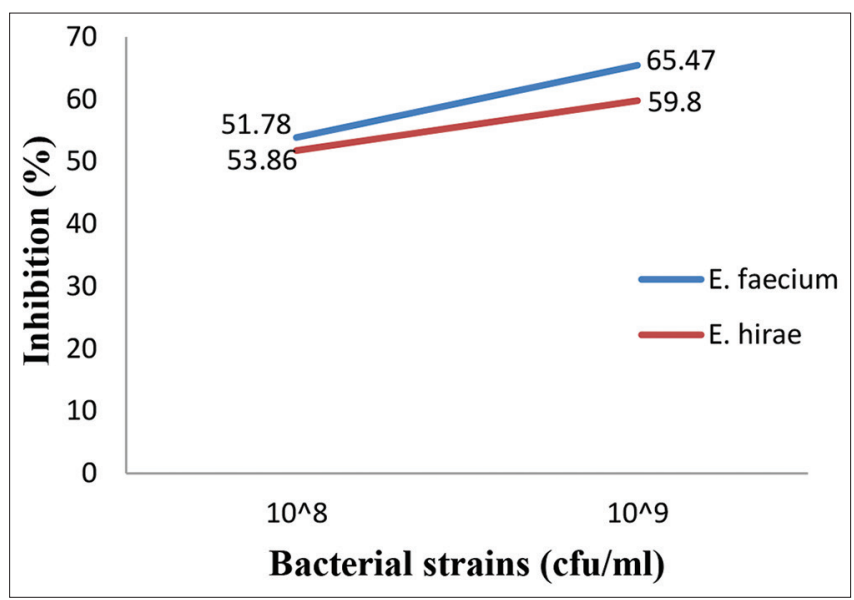

Fig. 1: Antioxidant activities of bacterial strains Enterococcus faecium and Enterococcus hirae 
$(p<0.05)$ lowering of BGL and a rise in body weights. Treatment of probiotic bacteria improved body weight and decreased BGL in alloxaninduced rats.

\section{Acute toxicity assay}

Cell suspensions of E. faecium and $E$. hirae were safe up to the highest dose of $10^{10} \mathrm{cfu} / \mathrm{ml}$. The animal's behavior was observed for the first $4 \mathrm{~h}$ followed by an interval of every $6 \mathrm{~h}$ up to $72 \mathrm{~h}$. Any physical sign of toxicity was not shown in albino rats by the bacterial cultures during the experiment and no mortalities were rewarded.

\section{Effect of probiotic strains on BGL}

Probiotic bacteria significantly $(\mathrm{p}<0.01)$ resulted in a dose-dependent reduction of BGL in alloxan-induced diabetic rats. Alloxanized rats of Group II (negative control) suffered from hyperglycemia as they did not receive any drug, whereas alloxanized rats of Group III (positive control) treated with the reference antidiabetic drug glibenclamide showed a significant reduction in BGL to the required standard BGL on the $14^{\text {th }}$ day and the BGLs $(116.50 \mathrm{mg} / \mathrm{dL})$ were completely controlled under $21^{\text {st }}$ day. The rats of Groups IV and V treated with E. faecium at doses of $10^{8} \mathrm{cfu} / \mathrm{ml}$ and $10^{9} \mathrm{cfu} / \mathrm{ml}$, respectively, showed the decreases in BGL to $165.83 \mathrm{mg} / \mathrm{dL}$ and $143.66 \mathrm{mg} / \mathrm{dL}$, respectively, which was close to the positive control group. However, Groups VI and VII rats treated with E. hirae at doses of $10^{8} \mathrm{cfu} / \mathrm{ml}$ and $10^{9} \mathrm{cfu} / \mathrm{ml}$, respectively, and also showed the BGL of $173.16 \mathrm{mg} / \mathrm{dL}$ and $156.33 \mathrm{mg} / \mathrm{dL}$, respectively, on $21^{\text {st }}$ day. Positive control glibenclamide showed BGL normalized $116.50 \mathrm{mg} / \mathrm{dL}$ on $21^{\text {st }}$ day, whereas E. faecium at the dose of $10^{\circ} \mathrm{cfu} / \mathrm{ml}$ treated rats attained normal BGL of $143.66 \mathrm{mg} / \mathrm{dL}$ on the $21^{\text {st }}$ day (Table 1 ).

\section{Effect of probiotic strains on body weight of animals}

There was a simultaneous increase in the body weight (139.16-148.16g) of normal control rats during the experimental period $0,3^{\text {rd }}, 7^{\text {th }}, 14^{\text {th }}$, and $21^{\text {st }}$ days. All groups displayed the same bodyweight on 0 days, but the treated groups showed different body weight after the $3^{\text {rd }}$ day. Group II diabetic control had the body weight ( $146.50 \mathrm{~g})$ same as control groups for 0 days, but the diabetic group showed a decrease in body weight (137.66-89.50 g) the $3^{\text {rd }}$ day. Group III (glibenclamide drug) exhibited the increasing body weight (118.66-136.66 g) continuously during the experiment. Groups IV and V treated with E. faecium showed ascended body weight (111.83-126.66 $\mathrm{g}$ at dose of $10^{8} \mathrm{cfu} / \mathrm{ml}$ and $114.83-$ $132.33 \mathrm{~g}$ at dose of $\left.10^{9} \mathrm{cfu} / \mathrm{ml}\right)$. Groups VI and VII treated with E. hirae ascended the body weight (109.33-124.83 g at dose of $10^{8} \mathrm{cfu} / \mathrm{ml}$ and $112.16-129.33 \mathrm{~g}$ at dose of $10^{9} \mathrm{cfu} / \mathrm{ml}$ ) on $3^{\text {rd }}, 7^{\text {th }}, 14^{\text {th }}$, and $21^{\text {st }}$ days and showed similarity with the control group. However, E. faecium at doses of $10^{9} \mathrm{cfu} / \mathrm{ml}$ resulted in an increase in the bodyweight of rats as compared to positive control (Table 2).

\section{Scanning electron microscopy of excised rat intestine}

The presence of a large number of cells of Escherichia coli and Salmonella typhimurium was observed under the scanning electron micrograph of the small intestine of rats. While the treated rats were displayed the coccus-shaped cells of E. faecium. These E. faecium bacterial cells were aggregated with the consortium of different pathogens (Fig. 2).

\section{DISCUSSION}

This study was carried out to investigate the antioxidant activity, intestinal attachment and in vivo antidiabetic effect of two probiotics Enterococcus spp. in diabetic animals containing alloxan. The antioxidant effects of Enterococcus spp. were observed by the DPPH radical scavenging method. An imbalance in a large number of ROS and low antioxidant capacity is known as oxidative stress. The increased generation of ROS causes damage to cells, tissues, and biomolecules. ROS generation usually leads to cellular damage through several mechanisms, such as oxidation, interference with nitric oxide, and modulation of detrimental intracellular signaling pathways [14].

Animals with diabetes, obesity, hyperglycemia, and cholesterol induced by alloxan exhibited similar disease symptoms as in humans. The BGLs increase 3-4 times in alloxan-induced diabetic rats as compared to a normal control group. The pancreatic tissues decrease utilization of glucose or produce glucose, lipid in an excess amount that causes hyperglycemia in diabetes mellitus [15]. Alloxan has been shown to induce free-radical production. The formation of ROS like free-radical reduces the $\beta$-cells and causes tissue injury. The action of alloxan-induced free-radical damage is especially susceptible by the pancreas [16].

Table 1: Effect of probiotic E. faecium and E. hirae strains on blood glucose levels in alloxan-induced albino rats

\begin{tabular}{|c|c|c|c|c|c|c|}
\hline \multirow[t]{2}{*}{ Groups } & \multirow[t]{2}{*}{ Dose } & \multicolumn{5}{|c|}{ Blood glucose concentration (mg/dl) } \\
\hline & & 0 day & $3^{\text {rd }}$ day & $7^{\text {th }}$ day & $14^{\text {th }}$ day & $21^{\text {st }}$ day \\
\hline Control & Normal saline & $81.16 \pm 1.06$ & $82.33 \pm 1.10$ & $84.83 \pm 2.26$ & $85.16 \pm 1.34$ & $85.16 \pm 1.34$ \\
\hline Glibenclamide & $50 \mathrm{mg} / \mathrm{kg}$ & $83.16 \pm 1.06$ & $229.83 \pm 1.34^{*}$ & $217.16 \pm 2.40^{*}$ & $193.83 \pm 1.06^{*}$ & $116.50 \pm 1.70^{*}$ \\
\hline E. faecium & $10^{8} \mathrm{cfu} / \mathrm{ml}$ & $85.66 \pm 1.59$ & $236.66 \pm 1.10^{* *}$ & $229.16 \pm 0.68 *$ & $218.33 \pm 0.74^{*}$ & $165.83 \pm 1.77^{*}$ \\
\hline E. faecium & $10^{9} \mathrm{cfu} / \mathrm{ml}$ & $84.16 \pm 1.21$ & $232.83 \pm 1.77^{*}$ & $221.83 \pm 1.34^{*}$ & $204.16 \pm 2.11^{*}$ & $143.66 \pm 1.10^{*}$ \\
\hline E. hirae & $10^{8} \mathrm{cfu} / \mathrm{ml}$ & $86.16 \pm 1.34$ & $238.83 \pm 1.46^{* * *}$ & $231.83 \pm 1.57^{*}$ & $222.83 \pm 1.34 *$ & $173.16 \pm 1.06^{*}$ \\
\hline E. hirae & $10^{9} \mathrm{cfu} / \mathrm{ml}$ & $85.16 \pm 1.21$ & $235.66 \pm 0.74 * *$ & $226.66 \pm 0.74 *$ & $211.50 \pm 1.70 *$ & $156.33 \pm 0.74 *$ \\
\hline
\end{tabular}

The values are mean \pm SD of six rats in each group. One-way ANOVA followed by t-test: Two sample assuming equal variances; ${ }^{* * *} P<0.05,{ }^{* *} P<0.01,{ }^{*} P<0.001$ as compared to diabetic control. E. faecium: Enterococcus faecium, E. hirae: Enterococcus hirae

Table 2: Effect of probiotic E. faecium and $E$. hirae strains on body weight of alloxan-induced albino rats

\begin{tabular}{|c|c|c|c|c|c|c|}
\hline \multirow[t]{2}{*}{ Groups } & \multirow[t]{2}{*}{ Dose } & \multicolumn{5}{|c|}{ Body weight (g) } \\
\hline & & 0 day & $3^{\text {rd day }}$ & $7^{\text {th }}$ day & $14^{\text {th }}$ day & $21^{\text {st }}$ day \\
\hline Control & Normal saline & $139.33 \pm 1.24$ & $143.16 \pm 2.26$ & $144.16 \pm 1.57$ & $146.16 \pm 1.34$ & $148.16 \pm 0.89$ \\
\hline Diabetic control & $40 \mathrm{mg} / \mathrm{kg}$ & $146.50 \pm 1.50$ & $137.66 \pm 0.74$ & $127.50 \pm 3.14$ & $91.83 \pm 1.83$ & $89.50 \pm 1.11$ \\
\hline Glibenclamide & $50 \mathrm{mg} / \mathrm{kg}$ & $139.16 \pm 1.06$ & $118.66 \pm 1.10^{* *}$ & $121.83 \pm 1.34^{* * *}$ & $127.50 \pm 0.95^{*}$ & $136.66 \pm 1.10 *$ \\
\hline E. faecium & $10^{8} \mathrm{cfu} / \mathrm{ml}$ & $140.83 \pm 1.95$ & $111.83 \pm 1.06^{*}$ & $114.16 \pm 0.68^{*}$ & $118.33 \pm 0.74^{*}$ & $126.66 \pm 3.94 *$ \\
\hline E. faecium & $10^{9} \mathrm{cfu} / \mathrm{ml}$ & $142.16 \pm 1.34$ & $114.83 \pm 1.34^{*}$ & $117.83 \pm 0.68^{*}$ & $122.33 \pm 1.10^{*}$ & $132.33 \pm 1.10 *$ \\
\hline E. hirae & $10^{9} \mathrm{cfu} / \mathrm{ml}$ & $141.33 \pm 1.24$ & $112.16 \pm 1.06^{*}$ & $115.16 \pm 0.89 *$ & $120.66 \pm 2.80 *$ & $129.33 \pm 0.94 *$ \\
\hline
\end{tabular}

*The values are mean \pm SD of six rats in each group. One-way ANOVA followed by t-test: Two sample assuming equal variances; ${ }^{* * *} P<0.05,{ }^{* *} P<0.01,{ }^{*} P<0.001$ as compared to diabetic control. E. faecium: Enterococcus faecium, E. hirae: Enterococcus hirae 

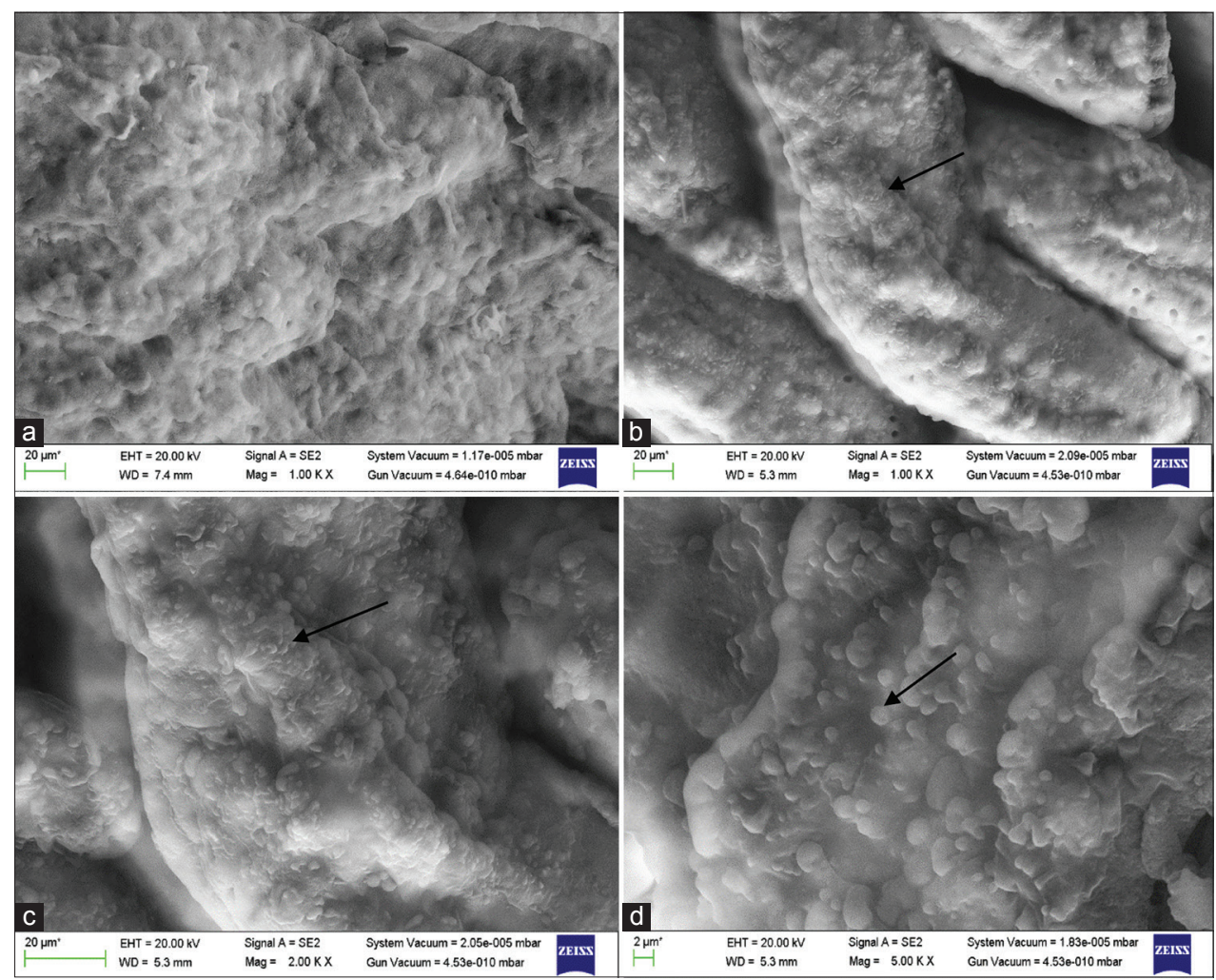

Fig. 2: Intestinal attachment of probiotic Enterococcus faecium; (a) control, group; (b) rats infected by consortium of different pathogens; (c) probiotic E. faecium aggregates with pathogenic bacterial cells; (d) coccus-shaped E. faecium in the intestine of the treated rats

Our results displayed that BGL reduced by the glibenclamide in hyperglycemias animals. In this condition, the state of diabetes is not severe. At the end of the experimental period, a significant reduction in BGL was recorded in alloxan-induced diabetes animals treated by probiotic bacteria as compared with diabetic control groups. Induction of diabetes with alloxan is associated with the characteristic loss of body weight, due to increased muscle wasting in diabetes. Moreover, the diabetic rats treated with the probiotic bacteria gained the body weight as compared with the diabetic control group. A marked increase was observed in serum triglycerides, cholesterol, and HDL in untreated diabetic rats. A similar finding has also been reported by Nikkila and Kekki [17]. Diabetic rats treated with the probiotic bacteria showed a significant decrease in cholesterol and triglycerides and an increase in HDL as compared with diabetic control. During diabetes, glycogen syntheses in the rat liver and skeletal muscles were reduced. Therefore, alloxan may produce oxygen radicals in the body. This causes pancreatic injury and could be responsible for increased blood glucose [18]. The antidiabetic effects of the E. faecium (doses of $10^{9} \mathrm{cfu} / \mathrm{ml}$ ) were almost similar to glibenclamide. This is a possible mechanism by which the probiotic bacteria have antidiabetic action due to potentiation of pancreatic secretion of insulin from existing residual $\beta$-cell of islets or improved the transport of blood glucose to peripheral [19].

In this study, the accumulative action of the probiotic bacterial strains might have a progressive reduction in the BGL of alloxan-diabetic rats during the treatment period and also associated with an increase in the blood insulin levels. In alloxan-diabetic rats, elevation in blood insulin by the probiotic bacterial treatment could be because of the high antioxidant activities exhibited by probiotic bacteria that encourage the protection of the functional $\beta$-cells from further deterioration or the $\beta$-cells regenerate so that they remain active and produce insulin. The probiotics have a significant role in the treatment or prevention of various chronic diseases, including diabetes by lowering the BGL as also confirmed in this study.

Adhesion of pathogenic bacteria to the surface of mucus is considered to be an initial step of intestinal infections. The adhesions of pathogens recognize specific mucosal receptors, which is mediated by bacterial adhesions. Adhesion may be inhibited with specific adhesion analogs by blocking the receptor. Therefore, inhibition of adhesion may prevent the colonization of the intestine by the pathogen and thereby prevent the infection. Some probiotic bacteria with helpful health effects have been found to adhere to the intestinal mucosa. Consequently, adherent probiotic bacteria could prevent the subsequent attachment of pathogens, and referred to as "competitive exclusion." In the intestine, epithelial cells are covered with a mucus layer protecting the epithelial cells from physical and chemical damage as well as from pathogenic bacteria [20]. The mucus layer is most likely the first place of contact between the host and the pathogen.

\section{CONCLUSION}

The present study demonstrates that the antioxidant and antidiabetic activity of probiotic bacterial strains, E. faecium and E. hirae. These bacteria exhibited the greatest antioxidant activity estimated through the scavenging of free radicals such as DPPH. Due to its potent antioxidant properties, free-radical scavenging in probiotic bacterial strains could be responsible for its antidiabetic effect. These probiotic bacterial strains reduced the glucose level and body weight gain in alloxan-induced diabetic rats. In addition, E. faecium may have modified the intestinal conditions by inhibiting the pathogens and pathogens adhering to the intestinal cell.

\section{ACKNOWLEDGMENTS}

The authors are thankful to the Head, Department of Botany and Microbiology for laboratory facilities the Head, Department of Pharmaceutical Science for Animal House facilities and Indian Institute Technology (Roorkee) for scanning electron microscopy.

\section{AUTHORS CONTRIBUTIONS}

Both the authors mutually contributed in preparation of research paper. 


\section{AUTHORS FUNDING}

No funding.

\section{CONFLICT OF INTEREST}

There is no conflict of interest.

\section{REFERENCES}

1. Steven D, Ehrlich N. Solutions Acupuncture: A Private Practice Specializing in Complementary and Alternative Medicine. Diabetes VeriMed Healthcare Network; 2012. Available from: http://www.umm. edu/health/medical/altmed/condition/diabetes. [Last accessed on 2014 Apr 13].

2. Caballero AE, Arora S, Saouaf R, Lim SC, Smakowski P, Park JY, et al. Microvascular and macrovascular reactivity is reduced in subjects at risk for Type 2 diabetes. Diabetes 1999;48:1856-62

3. Farvid MS, Siasi F, Jalai M. The impact of Vitamin C and E, magnesium and Zinc on glycemic control and insulin resistance in Type II diabetic patients. Tehran Univ Med J 2006;64:67-75.

4. Ceriello A. New insights on oxidative stress and diabetic complications may lead to a "causal" antioxidant therapy. Diabetes Care 2003;26:1589-96.

5. Vijayakumar M, Govindarajan R, Rao GM, Rao CV, Shirwaikar A, Mehrotra S, et al. Action of Hygrophila auriculata against streptozotocininduced oxidative stress. J Ethnopharmacol 2006;104:356-61.

6. Prabhurajeshwar, C, Chandrakanth, RK. Development of in vitro methodologies for inhibition of pathogenic bacteria by potential probiotic Lactobacillus sps: An evidence for production of antimicrobial substances. Int J Pharm Pharm Sci 2016;8:277-86.

7. Gomes AC, Bueno AA, de Souza RG, Mota JF. Gut microbiota, probiotics and diabetes. Nutr J 2014;13:60.

8. Choudhary J, Dubey RC, Sengar G, Dheeman S. Evaluation of probiotic potential and safety assessment of Lactobacillus pentosus MMP4 isolated from mare's lactation. Probiotics Antimicrob Proteins
2018;11:403-12.

9. Debapriya M, Pratima R. Evaluation of probiotic and antimicrobial properties of lactobacillus strains isolated from dairy products. Int $\mathrm{J}$ Pharm Pharm Sci 2016;8:230-34

10. Rajput K, Dubey RC. Probiotic potential and safety characterization of Enterococcus hirae G24 isolated from indigenous raw goat milk. Int J Pharm Sci Drug Res 2020;12:1-9.

11. Heo SJ, Cha SH, Lee KW, Cho SM, Jeon YJ. Antioxidant activities of Chlorophyta and phaeophyta from Jeju Island. Algae 2005;20:251-60.

12. Saravanan R, Pari L. Antihyperlipidemic and antiperoxidative effect of Diasulin, a polyherbal formulation in alloxan induced hyperglycemic rats. BMC Complement Altern Med 2005;5:14.

13. Litchfield JJ, Wilcoxon F. A simplified method of evaluating doseeffect experiments. J Pharmacol Exp Ther 1949;96:99-113.

14. Duzguner V, Kaya S. Effect of zinc on the lipid peroxidation and the antioxidant defense systems of the alloxan-induced diabetic rabbits. Free Rad Biol Med 2007;42:1481-86.

15. Chang S, Hypolite JA, DiSanto ME, Changolkar A, Wein AJ, Chacko S. Increased basal phosphorylation of detrusor smooth muscle myosin in alloxan-induced diabetic rabbit is mediated by upregulation of Rhokinase $\beta$ and CPI-17. Am J Physiol Renal Physiol 2006;290:650-56.

16. Halliwell B, Gutteridge JM. Free radicals in biology and medicine. J Free Radic Biol Med 1985;1:331-34.

17. Nikkilä EA, Kekki M. Plasma triglyceride transport kinetics in diabetes mellitus. Metab Clin Exp 1973;22:1-22.

18. Huang X, Vaag A, Hansson M, Weng J, Laurila ES, Groop L. Impaired insulin-stimulated expression of the glycogen synthase gene in skeletal muscle of Type 2 diabetic patients is acquired rather than inherited. J Clin Endocrinol Metab 2000;85:1584-90.

19. Baynes JW. Role of oxidative stress in development of complications in diabetes. Diabetes 1991;40:405-12

20. Beachey EH. Bacterial adherence: Adhesin-receptor interactions mediating the attachment of bacteria to mucosal surfaces. J Infect Dis 1981;143:325-45. 